\title{
Complications of chronic otitis media: a retrospective analysis of 1293 cases
}

\author{
Kronik otitis media komplikasyonları: 1293 olgunun retrospektif analizi \\ Mustafa Karakaş', H. Hüseyin Balıkçı', M. Haluk Özkul', Şaban Çelebi', Özlem Bayram ${ }^{3}$ A. Alper Bayram ${ }^{3}$ \\ ${ }^{1}$ Department of Otorbinolaryngology, Kabramanmaraş Government Hospital, Kabramanmaraş, Turkey \\ ${ }^{2}$ Department of Otorhinolaryngology, Susebri Government Hospital, Sivas, Turkey \\ ${ }^{3}$ Department of Otorbinolaryngology, Haseki Training and Research Hospital, Istanbul, Turkey
}

\begin{abstract}
Objective: To evaluate the clinical signs and symptoms, diagnosis, treatments, outcomes, distribution and incidence of the complications of chronic otitis media (COM).

Methods: This retrospective study analyzed the clinical and operative findings of 1293 patients with COM, including 39 patients with complications of COM. We compared the surgical techniques, incidence and management of complications and morbidity and mortality rates with those reported in the relevant literature.

Results: Of the patients with complications, 23 were male and 16 were female. Eight patients (20.5\%) had intracranial complications, while $31(79.5 \%)$ had extracranial complications. Lateral sinus thrombophlebitis and labyrinthine fistula were the most common intra- and extracranial complication, respectively. Of the 39 patients with complications, 27 underwent radical mastoidectomy, including two patients who underwent simultaneous labyrinthectomy. Revision radical mastoidectomy, canal wall down tympanomastoidectomy and canal wall up tympanomastoidectomy were performed in one, six and five patients, respectively. All patients did well, and the mortality rate was $0 \%$ during a follow-up period of $46 \pm 22$ months.

Conclusion: Despite their reduced incidence, COM complications continue to pose a great, clinical challenge. A careful history, physical examination, effective use of imaging technology and most importantly, a greater awareness of COM complications will reduce their morbidity and mortality.
\end{abstract}

Keywords: Otitis media, suppurative, complications, cholesteatoma.

Complications of chronic otitis media (COM) occur when the ear infection spreads to structures outside the middle

\begin{abstract}
Özet
Amaç: Kronik otitis medianın klinik bulgu ve semptomlarının, tanı ve tedavi sonuçları ile birlikte dağılım ve insidansının değerlendirilmesi amaçlanmıştır.

Yöntem: Bu çalışmada kronik otitis media tanısı konulan 1293 hasta içerisinde komplikasyon saptanan 39 hastanın klinik ve operatif bulguları retrospektif olarak incelendi. Uygulanan cerrahi teknik, komplikasyonların insidansı ve yönetimi, hastaların morbiditesi ve mortalitesi ilgili literatür ile karşılaştırıldı.

Bulgular: Olguların \%58.9'u (n=23) erkek ve \%41.1'i (n=16) kadındır. Olguların 8'i (\%20.5) intrakraniyal komplikasyon ve 31'i (\% 79.5) ise ekstrakraniyal komplikasyon idi. İntrakraniyal komplikasyonlardan lateral sinüs trombozu (\%50), ekstrakraniyal komplikasyonlardan ise labirent fistülü (\%64.5) en sık komplikasyon olarak tespit edildi. Komplikasyon gelişen hastalardaki en sık semptomlar otore, işitme kaybı ve baş dönmesi idi. Komplikasyonu olan 39 hastanın 27'sine (\%69.2) radikal mastoidektomi, bu hastalarında 2'sine eş zamanlı olarak labirentektomi yapılmıştır. Sırasıyla bir (\%2.5) hastaya revizyon radikal mastoidektomi, 6 (\%15.5) hastaya kanal wall down timpanomastoidektomi, 5 (\%12.8) hastaya da kanal wall up timpanomastoidektomi yapılmıştır. Tüm hastalar iyileşmiş ve ortalama $46 \pm 22$ aylık takip süresinde mortalite oranı \%0'dır. Sonuç: Otojen komplikasyonlar, günümüzde azalmasına rağmen yaşamı tehdit etmeye devam etmektedirler. Dikkatli bir anamnez, fizik muayene, görüntüleme yöntemlerinin etkin kullanımı ve en önemlisi komplikasyondan şüphelenmek komplikasyonlara bağlı morbidite ve mortaliteyi azaltacaktır.
\end{abstract}

Anahtar sözcükler: Otitis media, süpüratif, komplikasyonlar, kolestatom. ear mucosa, and the air spaces of the temporal bone. The spread of infection can occur via preformed pathways, bone
Correspondence: Şaban Çelebi, MD. Department of Otorhinolaryngology, Haseki Training and Research Hospital, Fatih, İstanbul, Turkey.

e-mail: celebisaban@hotmail.com

Received: July 3, 2014; Accepted: July 27, 2014
Online available at:

www.jmedupdates.org doi: $10.2399 / \mathrm{jmu} .2014002003$ QR code: 
erosion or thrombophlebitis of the veins. ${ }^{[1]}$ Complications of COM may be extracranial or intracranial, ${ }^{[2,3]}$ and most of these complications occur secondary to the cholesteatoma component of COM. These complications can present during the acute phase of COM or during topical or systemic medical treatment. ${ }^{[3]}$ The situation can mask the clinical symptoms of COM and prevent early diagnosis. ${ }^{[4]}$

In this study, we retrospectively reviewed the signs, symptoms, diagnosis, treatments, outcomes, distribution and incidence of the complications of COM.

\section{Patients and Methods}

A total of 1293 patients with COM, including 39 patients with complications of COM, were operated on between January 2008 and March 2012 in our tertiary referral health care centre. The protocol of this study was approved by our institution's ethics committee. The complications were classified as intra- and extracranial complications. The patients' age, sex, ear pathology, presenting symptoms, otoscopic and radiologic findings, type of surgical technique applied and complications were reviewed. Consultations with infectious disease specialists, neurologists or neurosurgeons were obtained when required. Computed tomography (CT), magnetic resonance imaging (MRI) and magnetic resonance venography were performed, as necessary. All patients received pre- and postoperative antibiotic therapy.

All data were analyzed using the SPSS software (ver. 15.0; SPSS Inc., Chicago, IL, USA). The number of patients in each complication group was compared using the $c h i$-square test. Values of $p$ less than 0.05 were considered statistically significant.

\section{Results}

Of the 1293 patients with COM who were operated on between January 2008 and March 2012 in our hospital, 275 patients $(21.1 \%)$ were preoperatively and/or intraoperatively diagnosed as cholesteatoma. Of the patients with cholesteatoma, $36(13.1 \%)$ presented with complications of COM. In addition, isolated polyp and/or granulation tissue was observed in three patients. Total complication rate among all COM patients was 3\% (39/1293).

Of 1293 patients, 638 (49.3\%) underwent tympanoplasty, and $655(50.7 \%)$ mastoidectomy. The mean age of the patients with complications of COM was $39.60 \pm 10.59$ (range, 13-66) years, and $58.9 \%(\mathrm{n}=23)$ of the patients with complications were male and $41.1 \%(n=16)$ were female.
Intracranial complications occurred in 8 , and extracranial complications in 31 patients $(79.5 \%)$. Lateral sinus thrombophlebitis (LST; 50\%, 4/8) and labyrinthine fistula $(64.5 \%, 20 / 31)$ were the most common intra- and extracranial complications, respectively. The labyrinthine fistulae involved the lateral semicircular canals in 19 patients (95\%) and both the lateral and superior semicircular canals in one patient (5\%). Two patients with labyrinthine fistulae were diagnosed with suppurative labyrinthitis and they developed total deafness. The other labyrinthine fistula was confined to the endochondral bone. All patients with intracranial complications, except one, had cholesteatoma.

Three patients with extracranial complications had multiple complications. One patient with a cerebrospinal fluid (CSF) fistula and facial paralysis had previously undergone radical mastoidectomy. None of the other patients with complications of COM had a history of ear surgery. In all, 50 patients with uncomplicated COM and cholesteatoma and 20 patients with intra- or extracranial complications of COM had defects of the bony ear canal where the tegmentum extended along the middle fossa dura. Fallopian canal dehiscence was present in $70(5.4 \%)$ of the total 1293 patients, $59(21.4 \%)$ of 275 patients with cholesteatoma and $20(51.2 \%)$ of 39 patients with COM complications.

The most common symptoms among the patients with complications were otorrhoea, hearing loss and dizziness, followed by ear pain, headache, nausea, vomiting, fever, neck stiffness and confusion. Of 39 patients with complications, $27(69.2 \%)$ underwent radical mastoidectomy, including two patients who underwent simultaneous labyrinthectomy. Revision radical mastoidectomy, canal wall down tympanomastoidectomy and canal wall up tympanomastoidectomy were performed in one $(2.5 \%)$, six (15.5\%) and five (12.8\%) patients, respectively (Fig. 1).

Two patients with complicated COM had meningitis and were followed up postoperatively in the infectious diseases department. One patient with complicated COM had otitic hydrocephalus and bilateral abducens nerve paralysis. The cranial nerve palsy was treated in the neurology department after the operation. Two patients with brain abscess required postoperative treatment in the intensive care unit. All patients did well, and the mortality rate was $0 \%$ during a follow-up period of $46 \pm 22$ months.

\section{Discussion}

In recent times, sophisticated radiologic imaging technology has facilitated the early diagnosis of both intra- and extracra- 
nial complications of COM. The advent of efficient antibiotic therapy has led to a decline in the incidence of COM and a significant improvement in the prognosis of this condition. ${ }^{[5,6]}$ The rate of COM complications has been reported as varying between $0.69-3.2$ percent. ${ }^{[3,7]}$ In our study, the rate of complications was 3 percent. The incidence of intracranial complications of COM has been reported to range between $0.04-0.33 \%$ in the literature. ${ }^{[3,7]}$ In our study, 7 of 275 (2.5\%) patients with cholesteatoma and 8 of $1293(0.06 \%)$ patients with COM had intracranial complications. Extracranial complications of COM are encountered more frequently than its intracranial complications. ${ }^{[7]}$ Samuel et al. reported an incidence rate of $0.13 \%$ for extracranial complications of $\mathrm{COM}^{[8]}$ The incidence of extracranial complications of COM in our study was $2.3 \%$, and the ratio between extraand intracranial complications was 3.8. The higher incidence of extracranial complications in our study relative to that of other international studies can be attributed to the low socioeconomic level of our patient population.

The most common extracranial complications of COM reported in the literature are mastoiditis and mastoid abscess, followed, in order of decreasing frequency by facial paralysis and labyrinthine fistula. ${ }^{[3,6]}$ Rupa and Raman reported that mastoid abscess accounts for $50 \%$ of all complications of COM. ${ }^{[5]}$ In our study, however, labyrinthine fistula was the most common extracranial complication (64.5\%), followed by facial paralysis [12.9\%] (Fig. 2). One patient had both labyrinthine fistula and facial paralysis, while another had both CSF fistula and mastoid abscess. Only one patient $(3.2 \%)$ had mastoid abscess in our study.

Gersdorff and Nouwen reported that labyrinthine fistula occurred in $7 \%$ of cholesteatoma patients in their large series. ${ }^{[9]}$ This rate was $7.2 \%$ in our study of 1293 patients. According to the literature, labyrinthine fistula occurs mostly in patients with recurrent cholesteatoma. ${ }^{[3,4]}$ However, all our patients with labyrinthine fistula had primary disease.

In patients with COM, facial paralysis can be caused by the neural destructive effect of purulent neuritis or the mass effect of cholesteatoma and granulation tissue. ${ }^{[4,5]}$ Kangnasarak et al. reported that facial paralysis occurred in $0.26 \%$ of 102 patients in their study, ${ }^{[7]}$ while we found that $0.30 \%$ and $1.09 \%$ in which one of cholesteatoma patients had facial paralysis. In our study, all patients with intracranial complications, except for one patient with facial dehiscence, also had cholesteatoma. Early interven-

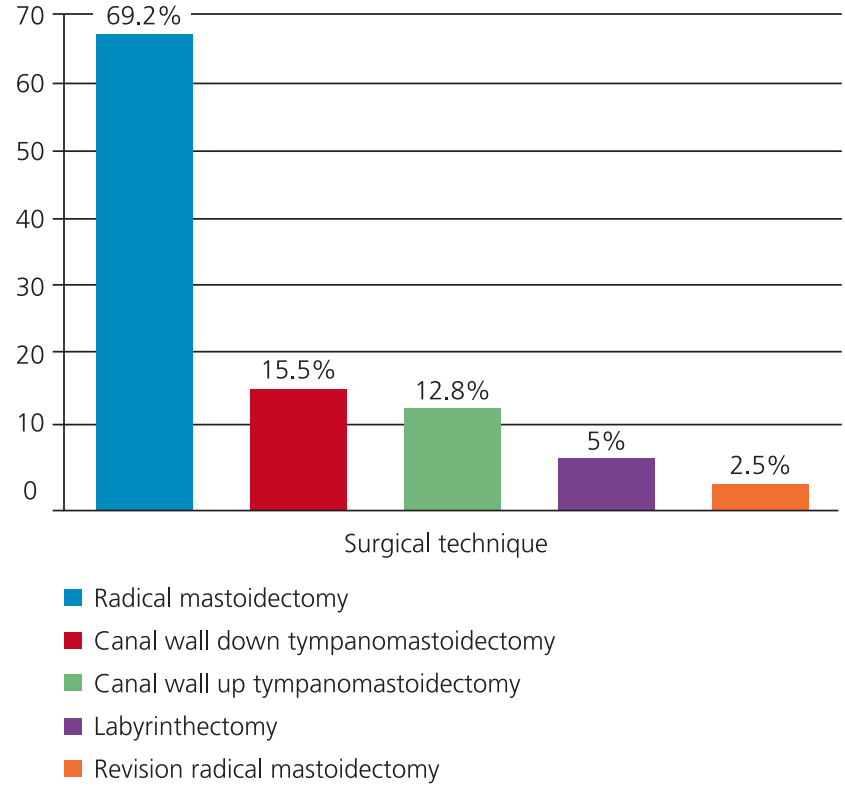

Fig. 1. Distribution of the surgical techniques used to manage chronic otitis media and its complications.

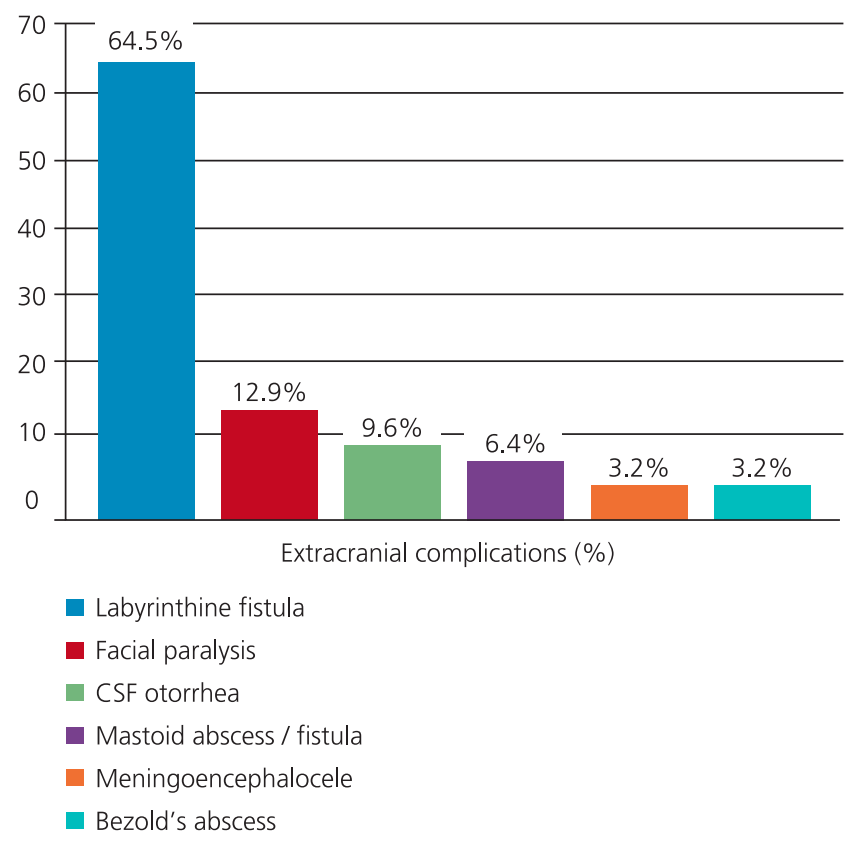

Fig. 2. Rate of extracranial complications of chronic otitis media.

tion should be performed in patients with COM complicated with facial paralysis. In our study, patients with facial paralysis were referred quite late to our clinic. All these patients underwent both radical mastoidectomy and facial 
decompression, but unfortunately, none of them recovered from the facial paralysis.

CSF otorrhoea is a rare complication of COM and is most commonly caused by iatrogenic trauma. Only 19 cases of CSF otorrhoea were reported in a 2007 metaanalysis performed by Bhat and Manjunath. ${ }^{[10]}$ There were three patients with CSF otorrhoea in our series. Two of these had cholesteatoma; the third had both CSF otorrhoea and facial paralysis and had previously been operated on for COM at a different centre, but still had recurrent cholesteatoma. All three patients underwent radical mastoidectomy and duraplasty in the same session.

In patients with COM, LST occurs either due to the extension of the infection into the mastoid cells or thrombophlebitis of the veins in the middle ear. ${ }^{[8]}$ Lateral sinus thrombophlebitis was the most common (50\%) intracranial complication in our series (Fig. 3), but has been reported as the third or fourth most common in other studies. ${ }^{[2,11,12]}$ However, Mostafa et al. also found that LST was the most common intracranial complication of COM, which is consistent with our series. ${ }^{[13]}$ The gold standard radiological method for the diagnosis of LST is MR venography (Fig. 4). The incidence of LST has been reported as 17.4-19\%, with a mortality rate of $10 \%{ }^{[7,8]}$ The treatment of LST is either needle aspiration of the infected thrombus or the excision of the thrombus by incising the lateral sinus. ${ }^{[13-15]}$ Seven et al. claimed that there was no difference between these two approaches. ${ }^{[2]}$ The latest studies have revealed that removal of the infected granulation tissue, without thrombus, is suf-

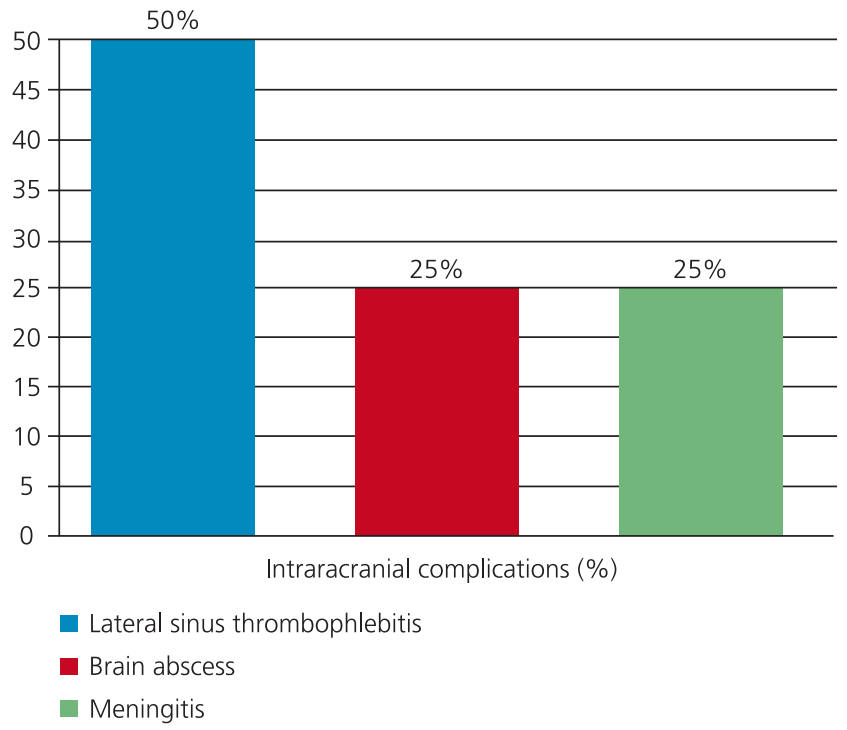

Fig. 3. Rate of intracranial complications of chronic otitis media.

ficient for recanalization of the sinus. ${ }^{[2,14]}$ In our study, all four patients with LST underwent radical mastoidectomy together with removal of the infected thrombus through an incision in the sinus wall. The use of anticoagulant therapy after surgery for LST is controversial, and many authors have advocated that this therapy should not be used because of the risk of septic embolus. ${ }^{[1,16-18]}$ Anticoagulant therapy may be useful in LST patients who develop persistent fever and neurologic changes indicative of septic embolus. ${ }^{[19]}$ In
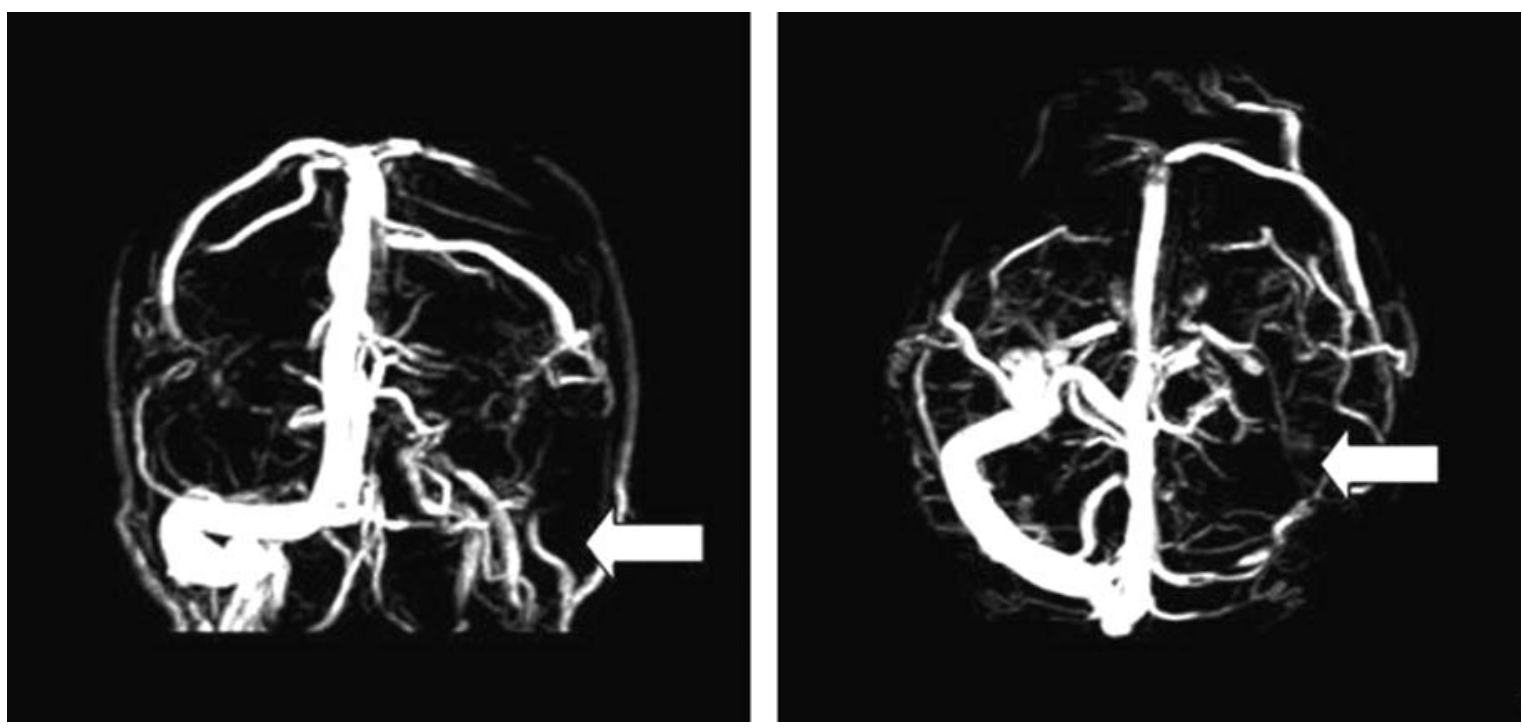

Fig. 4. Magnetic resonance venography in a patient with lateral sinus thrombophlebitis (arrow). 

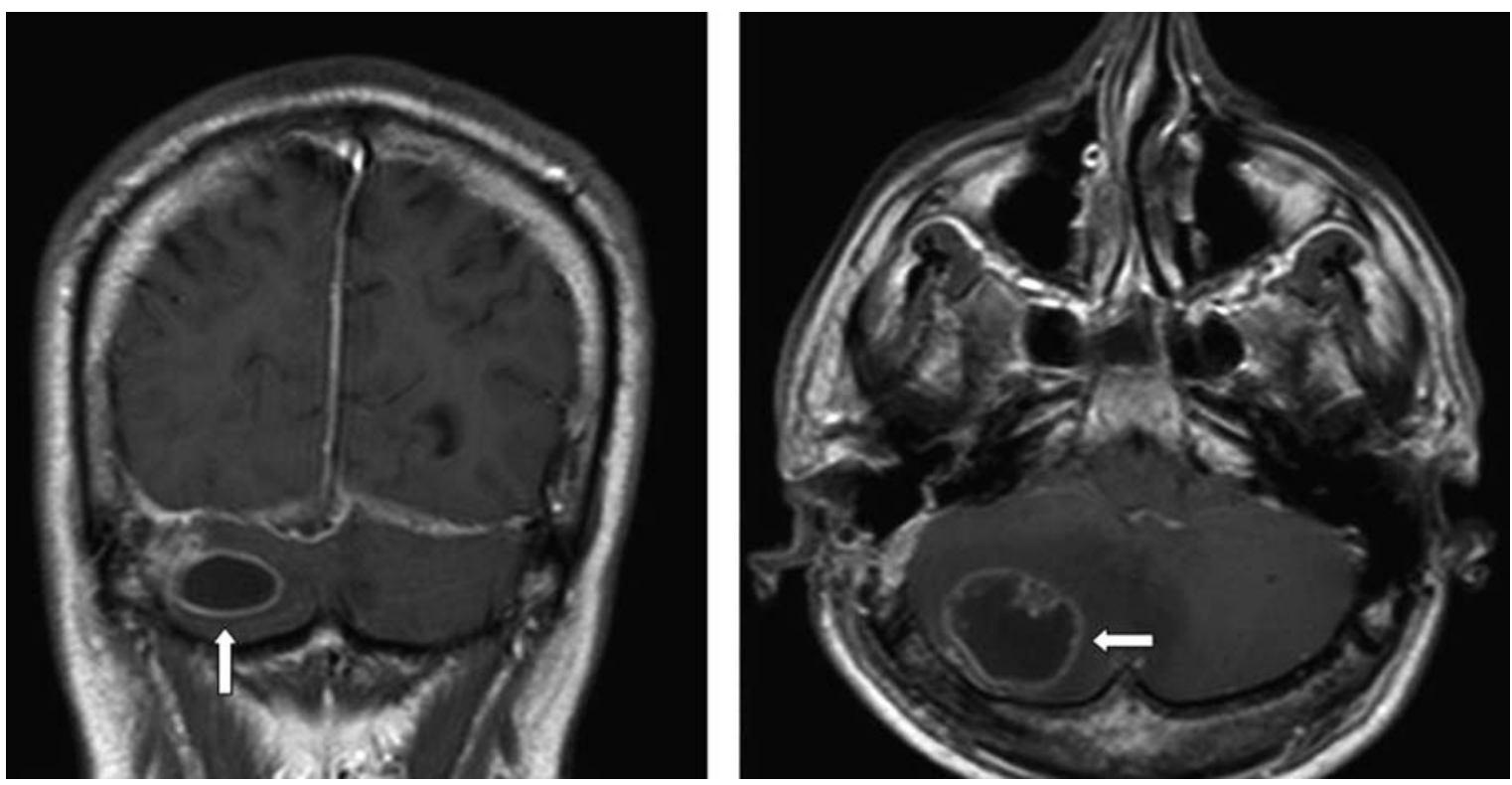

Fig. 5. Magnetic resonance imaging in a patient with a cerebellar abscess (arrow).

two patients with LST, the jugular veins were ligated. All LST patients, including those with otitic hydrocephalus and sixth cranial nerve paralysis, were discharged uneventfully.

Singh and Maharaj reported a $12 \%$ prevalence of meningitis. Neck stiffness and headache are the major symptoms of meningitis. ${ }^{[20]}$ The diagnosis is based on the results of a lumbar puncture and bacterial culture. Surgery is performed only after medical therapy has improved the vital signs of the patient. In our study, the two patients with otogenic meningitis underwent radical mastoidectomy after receiving medical therapy and were discharged uneventfully.

The most fatal and the second most common intracranial complication of COM is brain abscess (Fig. 5). ${ }^{[11]} \mathrm{In}$ our series also, brain abscess was the second most common intracranial complication. One patient with brain abscess presented with encephalitis, while the other presented with only fever. Both patients had cholesteatoma and underwent radical mastoidectomy, with no mortality.

\section{Conclusion}

The complications of COM continue to be life-threatening, although fortunately, their incidence is currently in decline. Patients with these complications tend to be those who have not received medical treatment, those who are from a low socioeconomic background and those who have previously refused surgery. Early diagnosis is of utmost importance to decrease the morbidity and mortality of complications of
COM. The treating physician must look for potential complications in patients who present with severe headache, ear pain, foul-smelling ear discharge, nausea, vomiting and/or persistent fever accompanying active COM. Since the therapy may necessitate a multidisciplinary approach, the cooperation of otorhinolaryngologists, infection disease specialists, neurologists and neurosurgeons is required.

Conflict of Interest: No conflicts declared.

\section{References}

1. Dubey SP, Larawin V, Molumi CP. Intracranial spread of chronic middle ear suppuration. Am J Otolaryngol 2010;31:73-7.

2. Seven H, Coskun BU, Calis AB, Sayin I, Turgut S. Intracranial abscesses associated with chronic suppurative otitis media. Eur Arch Otorhinolaryngol 2005;262:847-51.

3. Osma U, Cureoglu S, Hosoglu S. The complications of chronic otitis media. J Laryngol Otol 2000;114:97-100.

4. Gower D, McGuirt WF. Intracranial complications of acute and chronic infectious ear disease: a problem still wit us. Laryngoscope 1983;93:1028-33.

5. Rupa V, Raman R. Chronic suppurative otitis media: complicated versus uncomplicated deisease. Acta Otolaryngol 1991;111: 530-5.

6. Dubey SP, Larawin V. Complications of chronic suppurative otitis media and their management. Laryngoscope 2007;117:264-7.

7. Kangsanarak J, Fooanant S, Ruckphaopunt K, Navacharoen N, Teotrakul S. Extracranial and intracranial complications of suppurative otitis media. Report of 102 cases. J Laryngol Otol 1993; 107:999-1004. 
8. Samuel J, Fernandes CM, Steinberg JL. Intracranial otogenic complications: a persisting problem. Laryngoscope 1986;96:272-8.

9. Gersdorff MC, Nouwen J, Decat M, Degol JC, Bosch P. Labryinthine fistula after cholesteatomatous chronic otitis media. Am J Otol 2000;21:32-5.

10. Bhat V, Manjunath D. Cerebrospinal fluid otorrhea presenting in complicated chronic suppurative otitis media. Ear Nose Throat J 2007;86:223-5.

11. Kangsanarak J, Navacharoen N, Foonant S, Ruckphaopunt K. Intracranial complications of suppurative otitis media: 13 years' experience.. Am J Otol 1995;16:104-9.

12. Viswanatha B, Naseeruddin K. Lateral sinus thrombosis in otology: a review. Mediterr J Hematol Infect Dis 2010;2(3):e2010027.

13. Mostafa BE, El Fiky LM, El Sharnouby MM. Complications of suppurative otitis media: still a problem in the 21st century. ORL J Otorhinolaryngol Relat Spec 2009;71:87-92.

14. Samuel J, Fernandes CM. Lateral sinus thrombosis (a review of 45 cases). J Laryngol Otol 1987;101:1227-9.
15. Ooi EH, Hilton M, Hunter G. Management of lateral sinus thrombosis: update and literature review. J Laryngol Otol 2003; 117:932-9.

16. Shah UK, Jubelirer TF, Fish JD, Elden LM. A caution regarding the use of low-molecular weight heparin in pediatric otogenic lateral sinus thrombosis. Int J Pediatr Otorhinolaryngol 2007;71: 347-51.

17. Kuczkowski J, Mikaszewski B. Intracranial complications of acute and chronic mastoiditis: report of two cases in children. Int J Pediatr Otorhinolaryngol 2001;60:227-37.

18. Lee JH, Choi SJ, Park K, Choung YH. Managements for lateral sinus thrombosis: does it need the ligation of internal jugular vein or anticoagulants? Eur Arch Otorhinolaryngol 2009;266: $51-8$.

19. Bradley DT, Hashisaki GT, Mason JC. Otogenic sigmoid sinus thrombosis: what is the role of anticoagulation? Laryngoscope 2002;112:1726-9.

20. Singh B, Maharaj TJ. Radical mastoidectomy. J Laryngol Otol 1993;107:1113-8

This is an open access article distributed under the terms of the Creative Commons Attribution-NonCommercial-NoDerivs 3.0 Unported (CC BYNC-ND3.0) Licence (http://creativecommons.org/licenses/by-nc-nd/3.0/) which permits unrestricted noncommercial use, distribution, and reproduction in any medium, provided the original work is properly cited.

Please cite this article as: Karakaş M, Balıkçı HH, Özkul MH, Çelebi Ş, Bayram Ö, Bayram AA. Complications of chronic otitis media: a retrospective analysis of 1293 cases. J Med Updates 2014;4(2):43-48. 